\title{
IMPUGNAÇÃO AO CUMPRIMENTO DE SENTENÇA POR INCONSTITUCIONALIDADE
}

\author{
ENFORCEMENT OF JUDGMENT BY UNCONSTITUTIONALITY
}

\author{
Thiago Caversan Antunes" \\ Luiz Fernando Bellinetti"
}

\begin{abstract}
Resumo: Trata da impugnação ao cumprimento de sentença por inconstitucionalidade, com fundamento no artigo 475-L, $\S 1^{\circ}$, do Código de Processo Civil brasileiro. Parte de uma breve referência sobre a origem do dispositivo legal e sobre a sua constitucionalidade. Procura estabelecer qual a natureza dos efeitos de sua aplicação. Trata dos requisitos de aplicação da medida, em geral, de suas principais características e dos respectivos limites.
\end{abstract}

Palavras-chave: Cumprimento de Sentença. Sentença Inconstitucional. Impugnação.

Abstract: It deals with the enforcement of judgment by unconstitutionality with support in the article 475-L, $\S 1$, from the Brazilian Code of Civil Procedures. At first, it studies the origin of the legal rule and on its constitutionality. It tries to establish which is the nature of the effect of its application. It deals with the application requirements of the measure, in general, and of its main characteristics and the respective limits.

Key-words: Fulfilment of Judgment. Unconstitutional Judgment Enforcement of Judgment.

\section{INTRODUÇÃO}

O estudo que se apresenta procurará analisar as características, efeitos e limites de aplicação da impugnação ao cumprimento de sentença, por inconstitucionalidade, com fundamento no artigo 475-L, § 1ํㅡ, do Código de Processo Civil.

Procurar-se-á, assim, analisar, brevemente, as principais questões

Mestre em Direito Negocial pela Universidade Estadual de Londrina (UEL); professor do Curso de Graduação em Direito da Faculdade Norte Paranaense (UNINORTE) e do Núcleo de Prática Jurídica da Universidade Norte do Paraná (UNOPAR). E-mail: thcantunes@uol.com.br.

"* Doutor em Processo Civil pela Pontifícia Universidade Católica de São Paulo (PUCSP); professor do Curso de Graduação em Direito e do Programa de Mestrado em Direito Negocial, da Universidade Estadual de Londrina (UEL). Dados para contato: Departamento de Direito Privado, do Centro de Estudos Sociais Aplicados (CESA) da Universidade Estadual de Londrina (UEL). E-mail: luizbel@uol.com.br. 
contemporâneas ligadas ao instituto, que é relativamente recente no ordenamento jurídico brasileiro.

Neste particular, os esforços serão no sentido de estabelecer as origens do instituto e de investigar algo a respeito de sua constitucionalidade, inicialmente.

Adiante, procurar-se-á traçar algumas considerações mais específicas a respeito de suas características gerais, requisitos de aplicação e limites de alcance.

Também se procurará investigar se há hipóteses nas quais deve ser mantida a sentença impugnada, mesmo que tenha ela, eventualmente, tomado por fundamento algum dispositivo, interpretação ou aplicação pronunciado inconstitucional, por parte do Supremo Tribunal Federal.

É de se esclarecer, desde o início, que em vista da complexidade e vastidão da matéria, não se tem pretensões exaustivas, destinando-se, portanto, o artigo que ora se apresenta, exclusivamente, a levantar algumas importantes questões relacionadas ao tema, e a demonstrar a necessidade de análise mais aprofundada do objeto, por parte dos estudiosos das Ciências Jurídicas, em geral, e do Direito Processual Civil, em particular.

\section{ORIGEM}

A impugnação ao cumprimento de sentença, por inconstitucionalidade, encontra-se disciplinada pelo artigo 475-L, § 1ํㅡㄹ do Código de Processo Civil, segundo o qual se considera

[...] inexigível o título judicial fundado em lei ou ato normativo declarados inconstitucionais pelo Supremo Tribunal Federal, ou fundado em aplicação ou interpretação da lei ou ato normativo tidas pelo Supremo Tribunal Federal como incompatíveis com a Constituição Federal.

Apesar das relativas dificuldades para se estabelecer em que teria se inspirado o legislador, na criação do que viria a ser o parágrafo único do artigo 741 , do Código de Processo Civil, este dispositivo claramente determinou a redação do artigo 475-L, $\S 1^{\circ}$, do mesmo diploma legal, que constitui objeto central do estudo que ora se apresenta. ${ }^{1}$

Marinoni e Arenhart, todavia, ao tratar do artigo 475-L, § 1으, do Código de Processo Civil, vêem uma relação com a Lei 9.868/99, e desta com a Constituição portuguesa.

Segundo as exatas palavras dos próprios autores:

\footnotetext{
${ }^{1}$ Segundo a impressão de Montenegro Filho, "não há diferença de conteúdo entre os dispositivos em confronto. A Lei $\mathrm{n}^{\circ}$ 11.232/2005 apenas aperfeiçoou a redação da norma, tornando-a mais inteligível” (2006, p. 87).
} 
[...] a Constituição portuguesa, em que buscou inspiração o legislador brasileiro para editar a Lei 9.868/99 - que "dispõe sobre o processo e julgamento da ação direta de inconstitucionalidade e da ação declaratória de constitucionalidade perante o Supremo Tribunal Federal -, ao admitir a eficácia ex tunc da decisão de inconstitucionalidade (art. 282, n. 1), ressalva expressamente a coisa julgada material. Diz o art. 282, n. 3, da Constituição portuguesa, que "ficam ressalvados os casos julgados, salvo decisão em contrário do Tribunal Constitucional quando a norma respeitar a matéria penal, disciplinar ou de ilícito de mera ordenação social e for de conteúdo menos favorável ao arguido (MARINONI; ARENHART, 2008, p. 301).

Greco, por sua vez, refere-se à alteração do Código de Processo Civil, que culminou, inicialmente, com a criação, por Medida Provisória, dos embargos à execução contra a Fazenda Pública, por inconstitucionalidade, que, segundo o autor:

[...] ampliou a vulnerabilidade da coisa julgada através dos embargos à execução, com a introdução de parágrafo único ao artigo 741 do CPC, tornando inexigível a dívida se o título judicial se fundar lei ou ato normativo declarados inconstitucionais pelo Supremo Tribunal Federal ou em aplicação ou interpretação tidas por incompatíveis com a Constituição. Nela se nota a clara intenção de transpor para o Direito brasileiro a hipótese da parte final do § 79 da Lei Orgânica do Tribunal Constitucional Federal alemão, que preserva os efeitos pretéritos da coisa julgada, mas impede a execução futura (2002). ${ }^{2}$

Pode-se dizer, portanto, que a doutrina vê no artigo 475-L, § $1^{\circ}$, do Código de Processo Civil, uma influência diretamente européia, e ainda mais especificamente da Lei Orgânica do Tribunal Federal da Alemanha.

São elucidativas, desta forma, a título de maior esclarecimento, as observações de Oliveira, a respeito dos $§ \S 78$ e 79, da referida Lei Orgânica (2008, p. 50-1):

O § 78, 1ำ período, da Lei Orgânica da Corte Constitucional dispõe que "caso o Tribunal Federal constitucional forme a convicção de que o direito federal é incompatível com a Lei fundamental ou que o direito estadual conflita com a Lei Fundamental ou outro direito federal, deve declarar a sua nulidade”. Essa é a fórmula tradicional, que assenta na nulidade uma conseqüência lógica da

${ }^{2}$ Salienta, todavia, o autor que, em seu entendimento, no Brasil, "[...] o ilegítimo legislador governamental, com o sectarismo que o caracterizou nos últimos anos, importou a regra pela metade, ou seja, permitiu o bloqueio da execução, mas não garantiu a manutenção intacta dos efeitos pretéritos da coisa julgada. Também omitiu o legislador governamental a ressalva de que não cabe qualquer repetição do que tiver sido recebido com base na lei posteriormente declarada inconstitucional” (GRECO, 2002). 
inconstitucionalidade. O $2^{\circ}$ período do referido parágrafo, por sua vez, trata da extensão da declaração de nulidade, a qual poderá incidir sobre outros dispositivos da mesma lei (não impugnados) caso o Tribunal os considere inconstitucionais pelos mesmos fundamentos. Em que pese a nulidade absoluta da lei inconstitucional continue sendo dominante na tradição alemã, os efeitos ex tunc dessa decisão têm pouca relevância prática posto que a proteção da coisa julgada, estabelecida pelo $\S 79$ da Lei do Tribunal Constitucional como limite aos efeitos retroativos, implica na intocabilidade das sentenças transitadas em julgado mesmo quando tiver fundamento em norma declarada nula, com exceção das sentenças penais, as quais poderão ser revistas inclusive quando a decisão da Corte Constitucional for declaratória da mera incompatibilidade com a Lei Fundamental”.

Resta, assim, que a Lei Orgânica do Tribunal Federal Constitucional alemão trata, basicamente, no $\S 78$, dos efeitos da declaração de inconstitucionalidade de uma norma, no caso a nulidade, enquanto, no $\S 79$, traça uma limitação à sua eficácia, no que diz respeito aos efeitos passados de sentenças transitadas em julgado.

De acordo com a observação de Assis (2007, p. 1108):

[...] o $§ 79-2$ da Lei do Bundesverfassungsgericht estabelece que, apesar de remanescerem íntegros os provimentos judiciais proferidos com base em lei pronunciada inconstitucional, torna-se inadmissível (unzulässig) sua execução, aplicando-se o $§ 767$ da ZPO.

Segundo o autor, é precisamente neste $§ 767$, do Código de Processo Civil alemão, que teria o legislador buscado inspiração mais direta para introdução da impugnação ao cumprimento de sentença por inconstitucionalidade inicialmente, na realidade, dos respectivos embargos à execução contra a Fazenda Pública, por inconstitucionalidade - no ordenamento jurídico brasileiro. ${ }^{3}$

Isto porque, de acordo com o autor, "este parágrafo autoriza a oposição do executado (Vollstreckungsgegenklage) com base em exceções supervenientes ao trânsito em julgado” (ASSIS, 2007, p. 1108).

${ }^{3}$ Aliás, Assis menciona que "antes de o art. 741, parágrafo único, surgir na ordem jurídica brasileira, o STF estimava que, a despeito de a proclamação da inconstitucionalidade implicar o desaparecimento de todos os atos praticados sob o império da lei viciada, somente através de rescisória o vencido lograria alcançar a desconstituição do julgado. A 1 $1^{\text {o }}$ Turma do STF rejeitou, expressamente, o uso dos embargos contra a execução baseada em sentença posteriormente declarada inconstitucional. E o Pleno esclareceu que o julgamento do STF não se afigura eficaz perante a execução baseada em título formado nessas condições (2007, p. 1108). 
O fato, de toda sorte, é que, hodiernamente, a impugnação ao cumprimento de sentença, por inconstitucionalidade de dispositivo ou de interpretação que lhe tenha dado fundamentação, encontra-se positivada no artigo 475-L, $\S 1^{\circ}$, do Código de Processo Civil, que, por sua vez, foi inserido no ordenamento jurídico brasileiro por meio da Lei 11.232/2005, em vigor desde junho de 2006.

\section{CONSTITUCIONALIDADE}

Desde a criação do artigo 475-L, § $1^{\circ}$, do Código de Processo Civil, que introduziu no ordenamento jurídico a impugnação ao cumprimento de sentença, por inconstitucionalidade de seus fundamentos, tem havido grande debate na doutrina, a respeito da constitucionalidade do próprio instituto.

Parte da doutrina entende que o dispositivo legal em questão ofenderia a garantia constitucional da coisa julgada, que estaria inserta em cláusula pétrea e que não poderia, portanto, ser atingida, nem mesmo, por emenda constitucional.

Dinamarco, por exemplo, ao se pronunciar a este respeito, salienta que "pelo aspecto substancial, essa arbitrária disposição ao menos resvala na inconstitucionalidade por atentar contra a garantia constitucional da coisa julgada" (2009, p. 792-3). ${ }^{4}$

Entendimento semelhante é esposado por Marinoni e Arenhart (2008, p. 299), para quem:

Embora o Supremo Tribunal Federal venha chancelando - sem, todavia, enfrentar diretamente a questão da inconstitucionalidade da norma - o primitivo art. 741, parágrafo único, parece que essa norma e o $\S 1$ do art. 475-L são inconstitucionais, uma vez que negam a autoridade da coisa julgada material e, assim, um dos alicerces do Estado de Direito.

Parece possível afirmar, todavia, que o artigo 475-L, § 1ํㅡㄹ do Código de Processo Civil, não padece de inconstitucionalidade.

Isto porque, salvo melhor juízo, a garantia inserta no artigo 5으, XXXVI, da Constituição Federal, pretende, tão somente, que não se aplique previsão legal "nova", com efeitos retroativos, em prejuízo a uma decisão judicial transitada em julgado antes de seu advento.

Assim, ao tratar do dispositivo legal em questão, Assis pondera que não haveria ofensa aos termos da Constituição Federal, em geral, e à garantia da coisa julgada, em particular, e observa que:

${ }^{4} \mathrm{O}$ autor dá a entender, ainda, que considera inconstitucional a Medida Provisória 2.180-35, que inseriu o artigo 741, parágrafo único, no Código de Processo Civil, por absoluta inexistência de urgência para tanto (DINAMARCO, 2009, p. 792). 
[...] cabendo à lei infraconstitucional estabelecer quando e em que hipóteses há coisa julgada, também poderá instituir seu desaparecimento perante eventos contemporâneos ou supervenientes à emissão do pronunciamento apto a gerá-la (2007, p. 1110). ${ }^{5}$

Zavascki (2007) salienta com perspicácia que para se ter o dispositivo como substancialmente inconstitucional, teria que ser negada a constitucionalidade da própria ação rescisória, em suas palavras:

[...] ter-se-ia de negar a constitucionalidade da própria ação rescisória, instituto que evidencia claramente que a coisa julgada não tem caráter absoluto, comportando limitações, especialmente quando estabelecidas, como no caso, por via de legislação ordinária.

Vale dizer, portanto, que é possível imaginar a inconstitucionalidade da aplicação do artigo 475-L, § 1을 do Código de Processo Civil, quando se pretender dirigir a impugnação, com tal fundamento, contra o cumprimento de uma sentença transitada em julgado antes que entrasse em vigor a norma que inseriu o instituto no ordenamento jurídico; mas parece que não se poderia pretender que seja o instituto, em si, substancialmente inconstitucional.

\section{EFEITOS}

O artigo 475-L, § 1º , do Código de Processo Civil, também dá margem à considerável controvérsia, no que diz respeito a quais seriam os efeitos concretos de sua aplicação.

Vale, neste particular, preliminarmente, a menção aos termos expressos do dispositivo, segundo o qual "título judicial fundado em lei ou ato normativo declarados inconstitucionais pelo Supremo Tribunal Federal, ou fundado em aplicação ou interpretação da lei ou ato normativo tidas pelo Supremo Tribunal Federal como incompatíveis com a Constituição Federal” é considerado inexigível.

Dinamarco (2009, p. 792), todavia, traça duras críticas contra a redação do parágrafo em questão, e pontua que:

Um caso muito específico de inexistência de título executivo, expresso em lei, é o da sentença "fundada em lei ou ato normativo declarados inconstitucionais pelo Supremo Tribunal Federal ou em aplicação ou interpretação tidas como

\footnotetext{
${ }^{5}$ Registre-se, todavia, que Assis (2007, p. 1111) considera ser “[...] contraproducente sua incidência nas relações privadas, tout court, nas quais nenhuma necessidade há de uniformidade" e observa que, em seu entendimento, "a destruição retroativa da coisa julgada promoverá, ao contrário, a insegurança jurídica”.
} 
incompatíveis com a Constituição Federal” (CPC, art. 475-L, § 1으, e 741, par.). Os parágrafos que assim dispõem, de deplorável qualidade técnica porque redigidos sem o mínimo conhecimento da teoria do título executivo e do conceito de inexigibilidade, têm o significado de mandar que se considere inexistente o título nas hipóteses ali consideradas; não tem o menor significado a ideia de que um direito deixasse de ser exigível quando o título fosse assim viciado. ${ }^{6}$

Para o autor, portanto, em linhas gerais, a decisão judicial que acolhe uma impugnação com fundamento no artigo 475-L, § $1^{\circ}$, tem o efeito de declaração de inexistência do título judicial.

Zavascki, a seu lado, firmou o entendimento de que o deferimento desta espécie de impugnação teria eficácia rescisória da sentença contra a qual ele é dirigido (2005, p. 81 e 90).

A mesma opinião é compartilhada por Lucon ${ }^{7}$, para quem, aliás, o dispositivo "constitui um meio que o legislador encontrou para ampliar o prazo para a desconstituição da sentença transitada em julgado, que na ação rescisória, a teor do disposto no art. 495 do CPC, é de dois anos” (2006, p. 47).

Cabe aqui uma breve recapitulação a respeito dos efeitos da sentença que julga procedente uma ação rescisória:

O julgamento da ação rescisória, meio de impugnação à sentença transitada em julgado, comporta três etapas, preliminares uma da outra: juízo de admissibilidade da ação, no qual se examina a presença dos pressupostos processuais e das condições da ação; exame do pedido de rescisão do julgado, em que o órgão ad quem decide pela rescisão ou não da sentença (juízo rescindente) e, por fim, o rejulgamento da causa, se for o caso (juízo rescisório).

Tanto o iudicium rescindens quanto o iudicium rescissorium integram o juízo de mérito da ação rescisória. No primeiro, o Tribunal julgará o pedido procedente, se concluir pela presença de alguma das hipóteses previstas no art. 485 do CPC. Assim, admitida a ação, o juízo rescindente constituirá uma etapa necessária do julgamento da rescisória. Já o juízo rescisório poderá não se fazer presente, hipótese em que será desnecessário um rejulgamento da causa (PIMENTA, 2007, p. 146). ${ }^{8}$

${ }^{6}$ Pode ser esclarecedora das convicções do autor a afirmação de que "falta o título executivo quando o exeqüente simplesmente propõe a demanda executiva sem exibir documento algum com a intenção de afirmar que representa um título, ou quando ele se fundamenta em algo que afirma ser título executivo mas não está tipificado em lei como tal [...] (DINAMARCO, 2009, p. 791).

${ }^{7}$ Também assim entende Nery Junior, que identifica uma suposta "função rescisória" sempre que os embargos ou a impugnação versarem sobre "validade" ou "eficácia" da sentença de mérito transitada em julgado (2004, p. 52). 
Assim, o posicionamento doutrinário que considera ter a impugnação por inconstitucionalidade uma "eficácia rescisória", contudo, teria como conseqüência a necessidade de se considerar a decisão que aplica o artigo 475-L, $\S 1$ 을 do Código de Processo Civil, como "substitutiva" da sentença anterior, servindo, inclusive, como título executivo judicial para o até então "executado", mesmo para pleitear a repetição de eventuais parcelas da condenação que tenham sido cumpridas.

Todavia, este parece um elastecimento um tanto exagerado dos termos do próprio dispositivo legal em questão, que se limita a referir, como efeito da decisão que lhe dá aplicação, a "inexigibilidade" de um determinado título executivo judicial.

Assis (2007, p. 1113), ao tratar do tema, observa que o julgamento de procedência da impugnação ao cumprimento de sentença, com fundamento no artigo 475-L, § 1으 "implicará a inadmissibilidade da execução".

Salienta, todavia, o autor que "este provimento não desconstituirá o título, nem reabrirá o processo extinto" (ASSIS, 2007, p. 1113).

Parece, de toda sorte, conforme já anteriormente sugerido, aliás, que a melhor interpretação do artigo 475-L, § 1ำ é no sentido de que o provimento da impugnação que tenha tal dispositivo por fundamento implica, apenas, a "inexigibilidade" da obrigação inscrita no título judicial, conforme, aliás, determinação expressa de sua própria redação.

\section{PRAZO}

Há uma questão específica no que se refere à impugnação ao cumprimento de sentença, com fundamento no artigo 475-L, § 1º, do Código de Processo Civil, relacionada ao prazo de oferecimento, que merece alguma atenção.

Ocorre que, até o advento, primeiro, do artigo 741, parágrafo único, e, posteriormente, do artigo 475-L, § 1ำ o ordenamento jurídico brasileiro previa, como mecanismo específico de "impugnação à coisa julgada", a ação rescisória, para a qual era assinado o prazo de dois anos, a partir do trânsito em julgado da respectiva decisão.

Após o transcurso deste prazo, estaria extinta a possibilidade de utilização

\footnotetext{
${ }^{8}$ Segundo o autor, a inexistência de necessidade de prolação de um novo julgamento da causa, isto é, do judicium rescisorium, "é o que ocorre, por exemplo, quando o pedido da rescisória for julgado procedente, em face da presença dos pressupostos do art. 485, II, do CPC", e salienta que, "é possível, também, que o juízo rescindente esgote todo o objetivo da rescisória, como, por exemplo, na hipótese gizada pelo art. 485, IV, do CPC” (PIMENTA, 2007, p. 146).
} 
da ação rescisória como mecanismo específico de impugnação à coisa julgada; restando, ainda, para uma parcela da doutrina, a questionável possibilidade de "relativização da coisa julgada”, por meio de ações declaratórias, por exemplo. Assim, há na doutrina brasileira quem, analisando o artigo 475-L, § 1ํㅡㄹ veja, também, um óbice ao manejo da impugnação por inconstitucionalidade, após o transcurso do prazo para a ação rescisória (FUX, 2008, p. 268).

Isto poderia ocorrer quando o credor levasse um tempo considerável para requerer o cumprimento da sentença que lhe beneficia, ou, então, segundo a leitura contemporânea dominante do artigo 475-J, § 1으, quando o executado fosse intimado do auto de penhora e avaliação somente após um transcurso de tempo também relativamente longo. ${ }^{9}$

Em suma, para uma parcela de vozes respeitáveis da doutrina, ${ }^{10}$ quando, por qualquer circunstância, a impugnação ao cumprimento de sentença fosse protocolizada após o transcurso de mais de dois anos do trânsito em julgado, restaria inviabilizado o deferimento da pretensão de declaração de inexigibilidade do título, com fundamento no artigo 475-L, $\S 1^{\circ}$, por conta de uma suposta incompatibilidade com o artigo 495, do Código de Processo Civil.

Contudo, é de se destacar que parece mais adequada a interpretação de que a impugnação ao cumprimento de sentença não estaria sujeita ao prazo da ação rescisória, mesmo porque o próprio dispositivo legal que trata da questão não faz qualquer restrição desta ordem.

Assim é que Cramer, por exemplo, ao analisar os artigos 741, parágrafo único, e 475-L, § 1 , assevera: “[...] os embargos de devedor e a impugnação, com fundamento nesses dispositivos, não precisam ser oferecidos dentro do prazo bienal do art. 495 do CPC” (2008, p. 231). ${ }^{11}$

Desta forma, salvo melhor juízo, a impugnação ao cumprimento de sentença, por inconstitucionalidade, ficaria sujeita, apenas, ao seu próprio prazo, sendo indiferente, para os fins de sua aplicabilidade, que tenha, por qualquer circunstância, se verificado tal prazo após o termo que assinala a inviabilidade da ação rescisória.

\footnotetext{
9 E sem que antes disso tivesse oferecido uma primeira impugnação ao cumprimento de sentença.

${ }^{10}$ Vide, a este respeito, por exemplo, o próprio Fux (2008, p. 268).

${ }^{11}$ Da mesma forma, pronuncia-se Armelin (2004, p. 168).
} 


\section{EFEITOS DA COISA JULGADA ANTERIORES À IMPUGNAÇÃO}

Quando se trata da aplicação do artigo 475-L, § 1º, do Código de Processo Civil, há outro ponto que pode suscitar alguma controvérsia e que merece, portanto, referência, ainda que breve; e que está ligado aos efeitos da coisa julgada que se tenham verificado antes da propositura da impugnação ao cumprimento de sentença.

Em suma, é necessário saber se as parcelas da condenação que já tenham sido, eventualmente, adimplidas, quando do oferecimento da impugnação, por inconstitucionalidade, restariam atingidas, ou não, pela decisão judicial que the desse deferimento, e pronunciasse a inexigibilidade do título judicial.

Vale, a este respeito, uma pequena recapitulação do que se disse a respeito da origem do instituto, quando se demonstrou que o legislador brasileiro buscou, provavelmente, inspiração em legislação européia, para formular os artigos 741, parágrafo único, e 475-L, § 1ํㅡㄹ do Código de Processo Civil.

Assim, segundo a já referida lição de Greco, a "[...] parte final do $§ 79$ da Lei Orgânica do Tribunal Constitucional Federal alemão, [...] preserva os efeitos pretéritos da coisa julgada, mas impede a execução futura” (2002).

Parece possível aplicar semelhante sistemática à impugnação ao cumprimento de sentença, por inconstitucionalidade, em que pese o fato insofismável de que o artigo 475-L, $\S 1^{\circ}$ não trace, de forma clara e minuciosa, tais limites. ${ }^{12}$

Isto porque a própria redação do dispositivo legal em questão determina que a decisão que deferir a impugnação, por inconstitucionalidade, configurará uma situação de "inexigibilidade" da prestação inscrita no título judicial.

Parece claro, portanto, que deveria tal impugnação ser dirigida contra as pretensões do credor que sejam, na ocasião de seu oferecimento, inexigíveis.

Ocorre, todavia, que não parece adequado falar da "exigibilidade" de uma determinada parcela da condenação que já tenha sido prestada.

Vale dizer, ao que tudo indica, parece que a decisão que defere a impugnação, com fundamento no artigo 475 , $\S 1^{\circ}$, deve limitar os seus efeitos a reconhecer a inexigibilidade daquilo que é pleiteado pelo credor, com base em uma inconstitucionalidade.

12 Poder-se-ia argumentar que tal proposição implicaria um verdadeiro contra-senso, com o que se disse até o momento, tendo em vista que se tem negado, repetidamente, a conveniência das proposições que pretendem submeter a aplicabilidade do artigo 475-L, § 1, do Código de Processo Civil, a requisitos que não constem do próprio dispositivo legal. Ocorre, todavia, que, especificamente no que se refere aos chamados "efeitos pretéritos da coisa julgada", a inviabilidade de aplicação de tal espécie de impugnação salta, ao que parece, conforme se demonstrará da própria redação da norma que lhe regulamenta. 
Em suma, como bem deixa claro o dispositivo original alemão, o deferimento da impugnação por inconstitucionalidade deve surtir efeitos para o futuro, impedindo o prosseguimento da execução da parcela que lhe constituir objeto, mas não pode atingir os denominados "efeitos pretéritos da coisa julgada".

\section{HIPÓTESES DE MANUTENÇÃO DA SENTENÇA}

Pode se identificar, pelo menos, quatro hipóteses em que, ainda que se verifique a pronúncia de inconstitucionalidade, por parte do Supremo Tribunal Federal, de um dispositivo legal, interpretação ou aplicação que tenha dado fundamento a uma determinada sentença, poder-se-ia argüir a persistência da exigibilidade de tal título judicial: a) quando a parte dispositiva da sentença puder se manter, por outros fundamentos; b) quando à pronúncia de inconstitucionalidade tiverem sido atribuídos efeitos ex nunc, na forma do artigo 27, da Lei 9868 de 1999; c) quando a sentença tiver transitado em julgado antes da vigência do artigo 475-L, § $1^{\circ}$, por conta da vedação do artigo 5으. XXXVI, da Constituição Federal; e d) quando o Supremo Tribunal Federal tiver declarado, em controle incidental, no próprio caso concreto, a constitucionalidade da norma, aplicação ou interpretação.

Ao tratarem daquilo que aqui se identifica como a primeira hipótese de manutenção dos efeitos da sentença, Marinoni e Arenhart (2008, p. 300) observam:

Para que incida a situação, é necessário que a norma (ou a sua interpretação) seja decisiva para a formação da sentença de procedência. Ou melhor, se a questão da inconstitucionalidade for circunstancial, não se mostrando imprescindível para a manutenção da condenação, não se cogitará de inexigibilidade do título.

Lucon (2006, p. 46) também traça as suas considerações a respeito do tema, asseverando que:

Para que a declaração de inconstitucionalidade da norma determine a desconstituição do título executivo, é fundamental que a decisão judicial tenha alicerce exclusivo nessa norma. Se houver outro fundamento suficiente para lastrear a decisão, ela não pode ser desconstituída. Ademais, se a decisão tiver mais de um capítulo e esses capítulos forem autônomos, caso apenas um deles tenha fundamento em norma declarada inconstitucional pelo Supremo Tribunal Federal, não é possível a desconstituição do outro capítulo. ${ }^{13}$

\footnotetext{
${ }^{13}$ Assim também se manifesta Assis, para quem o julgamento de procedência dos embargos à execução contra a Fazenda Publica, com fundamento no artigo 741, parágrafo único - o que se aplica, também, à impugnação que tenha por fundamento o artigo 475-L, $\S 1$ - “[...] pressupõe a motivação do título executivo, exclusivamente, no preceito inconstitucional. Se, ao invés, a condenação se ampara em múltiplos
} 
Assim, a impugnação com base no artigo 475-L, § 1o somente poderia ser deferida quando por outros fundamentos não se possa manter aquela mesma condenação, isto é, quando o dispositivo, aplicação ou interpretação tido pelo Supremo Tribunal Federal como inconstitucional lhe seja determinante e indispensável.

Reconhecer que a exigibilidade da sentença deve ser mantida, ainda que o seu prolator tenha apontado qualquer fundamento inconstitucional, se por outros fundamentos a mesma conclusão puder se sustentar, aliás, faz muito sentido, já que, de outro modo, ter-se-ia que reconhecer, por exemplo, o dever jurídico (e, de forma reversa, também, o direito subjetivo) de o autor interpor recurso contra a decisão que, tendo-lhe dado tudo e exatamente o que pediu, tenha tomado fundamentos dos quais ele discorda, o que seria, no mínimo, indesejável.

Uma segunda hipótese de manutenção dos efeitos da sentença, que se poderia mencionar, ocorreria quando o Supremo Tribunal Federal pronunciasse a inconstitucionalidade de uma determinada norma, mas, utilizando-se da prerrogativa que lhe confere o artigo 27, da Lei 9868 , de 1999, conferisse à respectiva decisão efeitos ex nunc.

Desta forma, segundo a observação de Assis (2007, p. 1112):

Outorgando o STF efeitos ex nunc ao seu julgamento, com o fito de não bulir com direitos adquiridos sob a égide da lei inconstitucional, nenhuma aplicação exibe o art. 741, parágrafo único, às sentenças transitadas em julgado e baseadas no preceito controvertido. Em outras palavras, a alegação do julgado do STF, nos embargos, atenderá os limites temporais atribuídos à decisão, a teor do art. 27 da Lei 9.868/1999 e, em alguns casos, subsistirá incólume o título e, conseguintemente, a admissibilidade da execução nele fundada.

Neste caso, tendo o próprio Supremo Tribunal Federal reconhecido que há relevantes razões de segurança jurídica, ou um excepcional interesse social, e determinado que a pronúncia de inconstitucionalidade somente deverá produzir os seus efeitos a partir de um determinado momento, tendo a sentença transitado em julgado antes de tal momento, ou, ainda, quando a sentença, ainda

fundamentos, porque o vencedor alegou várias causas de pedir no processo que a originou, o título resistirá à inconstitucionalidade originária ou superveniente de apenas um dos seus fundamentos" (2007, p 1114). Da mesma forma se pronuncia Côrtes, segundo o qual "[...] a sentença que fez coisa julgada só será atingida pela declaração de inconstitucionalidade do STF se ela estiver baseada na norma inconstitucional e não puder sustentar-se por outro fundamento autônomo" (2007, p. 674). 
que proferida depois de tal prazo, tenha decidido situação jurídica anterior à vigência da determinação daquela Suprema Corte, não parece possível que se defira uma impugnação, com fundamento no artigo 475-L, $\S 1^{\circ}$, sob pena de se contrariar a própria determinação do Supremo Tribunal Federal. ${ }^{14}$

A terceira hipótese - que, aliás, deve se tornar cada vez menos comum - refere-se à manutenção dos efeitos da sentença que tenham transitado em julgado antes do advento do dispositivo legal que disciplina, hodiernamente, o cumprimento de sentença, por inconstitucionalidade.

A este respeito, ao comentar semelhante restrição no que se refere à aplicabilidade do artigo 741, parágrafo único, mas que muito bem se amolda ao mesmo problema, no que se refere ao artigo 475-L, § 1ํㅡ, salienta Zavascki (2007):

Sendo norma de natureza processual tem aplicação imediata, alcançando os processos em curso. Todavia, não pode ser aplicada retroativamente. Como todas as normas infraconstitucionais, também ela está sujeita à cláusula do art. 5, XXXVI, da Constituição, segundo a qual "a lei não prejudicará o direito adquirido, o ato jurídico perfeito e a coisa julgada”. Em observância a essa garantia, não há como supor legítima a invocação da eficácia rescisória dos embargos à execução relativamente às sentenças cujo trânsito em julgado tenha ocorrido em data anterior à da sua vigência. É que nesses casos há, em favor do beneficiado pela sentença, o direito adquirido de preservar a coisa julgada com a higidez própria do regime processual da época com que foi formada, e que não previa a sua rescisão por via de embargos. ${ }^{15}$

Assim, parece que a forma mais adequada de dar aplicação ao artigo $5^{\circ}$, XXXVI, da Constituição Federal, é considerar que, em relação às sentenças transitadas em julgado antes da vigência do dispositivo legal que trata da impugnação, por inconstitucionalidade, subsistiria, como meio de oposição específico, apenas a

${ }^{14} \mathrm{~A}$ este respeito, aliás, a observação de Carvalho, a respeito da ação rescisória, por inconstitucionalidade, quando o Supremo Tribunal Federal tenha modulado os efeitos de sua declaração, e que podem ser elucidativos, também, em relação à impugnação: “A restrição dos efeitos da decisão do STF salvaguarda a pós-atividade da decisão fundada em norma inconstitucional revestida pela autoridade da coisa julgada material. A garantia de preservação das situações anteriores à declaração de inconstitucionalidade da norma desautoriza o ajuizamento da ação rescisória” (2009, p. 22).

${ }^{15}$ Entendimento semelhante é desposado por Assis, para quem, "para não ofender ao art. 5으, XXXVI, da CF/1988, o art. 741, parágrafo único, somente se aplicará aos provimentos transitados em julgado após a vigência do art. 3o da MP 1.997-37, de 11.04.2000. Antes dessa data, vigora o regime anterior, ou seja, a alegação da inconstitucionalidade originária ou superveniente se veiculará através de ação rescisória” (2007, p. 1113). 
ação rescisória - desde que observados os requisitos pertinentes, inclusive em relação ao prazo.

Uma quarta hipótese que poderia, eventualmente, ser apontada por algum estudioso do tema ocorreria quando o Supremo Tribunal Federal tivesse pronunciado, no caso concreto, na fase de conhecimento, a constitucionalidade do dispositivo, aplicação ou interpretação que, em outra oportunidade, teria sido objeto de entendimento consolidado contrário, por aquela mesma suprema corte.

Este não parece, todavia, um caso em que se deva, invariavelmente, indeferir a impugnação e manter, a todo custo, os efeitos da sentença.

A possibilidade de impugnação ao cumprimento da sentença, por um entendimento consolidado de inconstitucionalidade de determinado dispositivo, aplicação ou interpretação, por parte do Supremo Tribunal Federal, ademais, parece ser exatamente o que resulta de uma leitura sistemática do artigo 102, I, j, da Constituição Federal, que prevê, em termos expressos, o cabimento de ação rescisória contra os seus julgados. ${ }^{16}$

\section{CONCLUSÃO}

Conforme salientado de início, o tema objeto do resumido artigo que ora se apresenta é vasto, e merece análise mais detida e aprofundada análise por parte dos estudiosos do Processo Civil.

Há, ainda, relevantes controvérsias, na melhor doutrina brasileira, a respeito dos mais variados aspectos relacionados à impugnação ao cumprimento de sentença, por inconstitucionalidade, com fundamento no artigo 475-L, $\S 1^{\circ}$, do Código de Processo Civil.

É possível apontar, contudo, algumas conclusões, se bem que inegavelmente não definitivas, a que se chegou no decorrer deste estudo.

Pode-se dizer, assim, ao que tudo indica, que a redação do artigo 475-L, § 1ํ, tem inspiração européia, ainda mais especificamente no $\S 767$, do Código de Processo Civil alemão, e nos $§ \S 78$ e79, da Lei Orgânica do Tribunal Federal Constitucional alemão.

Parece possível afirmar, também, a inconstitucionalidade de aplicação do artigo 475-L, § $1^{\circ}$, quando se pretender dirigir a impugnação nele fundamentada contra o cumprimento de uma sentença transitada em julgado antes da entrada em vigor da norma que inseriu tal instituto no ordenamento jurídico. Não parece, todavia, que o instituto em si, assim como ademais, a ação rescisória, padeça de inconstitucionalidade.

Em que pese à existência de acirrada controvérsia doutrinária a este respeito, parece que o mais adequado é considerar que o provimento da impugnação 
que tenha por fundamento o artigo 475-L, § 1을 implica a "inexigibilidade" da obrigação inscrita no título judicial, conforme determinação expressa de sua própria redação, e não em inexistência ou desconstituição do próprio título.

De outro lado, pode-se dizer que uma interpretação sistemática demonstraria que não fica a impugnação ao cumprimento de sentença, por inconstitucionalidade, sujeita ao prazo do artigo 495, do Código de Processo Civil, que se aplica, exclusivamente, à ação rescisória.

Acredita-se, também, que o deferimento da impugnação ao cumprimento de sentença, com fundamento no artigo 475-L, § 1, por implicar a "inexigibilidade" do título, deve surtir efeitos para o futuro, impedindo o prosseguimento da execução da parcela que lhe constituir objeto, ressalvados, todavia, eventuais adimplementos anteriores, ou seja, os "efeitos pretéritos da coisa julgada".

Os efeitos da sentença deverão ser, todavia, mantidos nos seguintes casos: quando a parte dispositiva da sentença puder se manter por outros fundamentos; quando os efeitos da pronúncia de inconstitucionalidade, pelo Supremo Tribunal Federal, tiverem sido modulados em prejuízo da aplicação do instituto, no caso concreto; e quando a sentença tiver transitado em julgado antes da vigência do artigo 475-L, § 1ํㅡㄹ do Código de Processo Civil.

É de se fazer a ressalva, porém, de que, por uma aplicação sistemática do artigo 102, I, j, da Constituição Federal, a declaração incidental, no caso concreto, por parte do Supremo Tribunal Federal, de constitucionalidade da norma, aplicação ou interpretação não inviabiliza o posterior oferecimento de impugnação ao cumprimento de sentença, por inconstitucionalidade, no mesmo caso.

\section{REFERÊNCIAS}

ARMELIN, Donaldo. Flexibilização da coisa julgada. São Paulo: Atlas, 2004.

ASSIS, Araken de. Manual da execução. 11. ed. São Paulo: Editora Revista dos Tribunais, 2007.

CARVALHO, Fabiano. Ação rescisória como meio de controle de decisão fundada em lei declarada inconstitucional pelo STF. Revista de Processo, São Paulo, v. 34, n. 170, p. 9-26, abr. de 2009.

CÔRTES, Osmar Mendes Paixão. A impugnação ao cumprimento de sentença, do art. 475-L do CPC, e a relativização da coisa julgada. In: SANTOS, Ernane Fidélis dos et. al. (Coord.). Execução civil: estudos em homenagem ao professor Humberto Theodoro Júnior. São Paulo: Editora Revista dos Tribunais, 2007.

CRAMER, Ronaldo. Impugnação da sentença transitada em julgado fundada 
em lei posteriormente declarada inconstitucional. Revista de Processo, São Paulo, v. 33, n. 164, p. 211-34, out. 2008.

DINAMARCO, Cândido Rangel. Instituições de Direito Processual Civil. São Paulo: Malheiros, 2009. v. 4.

FUX, Luiz. O novo processo de execução: o cumprimento de sentença e a execução extrajudicial. Rio de Janeiro: Forense, 2008.

GRECO, Leonardo. Eficácia da Declaração Erga Omnes de Constitucionalidade ou Inconstitucionalidade em relação à coisa julgada anterior. 2002. Disponível em: 〈http:// www.mundojuridico.adv.br/cgi-bin/upload/texto167.rtf〉. Acesso em: 30 dez. 2009.

LUCON, Paulo Henrique dos Santos. Coisa Julgada, Conteúdo e Efeitos da Sentença, Sentença Inconstitucional e Embargos à Execução contra a Fazenda Pública (ex vi art. 741, parágrafo único, do CPC). Revista de Processo, São Paulo, v. 31, n. 141, p. 20-52, nov. 2006.

MARINONI, Luiz Guilherme; ARENHART, Sérgio Cruz. Curso de Processo Civil. 2. ed. São Paulo: Editora Revista dos Tribunais, 2008. v. 3.

MONTENEGRO FILHO, Misael. Cumprimento da sentença e outras reformas processuais. São Paulo: Atlas, 2006.

NERY JUNIOR, Nelson. Princípios do processo civil na Constituição Federal. 8. ed. São Paulo: Editora Revista dos Tribunais, 2004.

OLIVEIRA, Aline Lima de. A limitação dos efeitos temporais da Declaração de Inconstitucionalidade no Brasil: uma análise da influência dos modelos norteamericano, austríaco e alemão. Porto Alegre: EDIPUCRS, 2008.

PIMENTA, Paulo Roberto Lyrio. Ação rescisória e modulação da eficácia temporal da decisão de inconstitucionalidade. Revista de Processo, São Paulo, v. 32, n. 153, p. 145-155, nov. de 2007.

ZAVASCKI, Teori Albino. Eficácia das sentenças na jurisdição constitucional. São Paulo: Editora Revista dos Tribunais, 2001.

. Embargos à execução com eficácia rescisória: sentido e alcance do art. 741, parágrafo único do CPC. 2007. Disponível em: <http://jus2.uol.com.br/ doutrina/texto.asp?id=10296>. Acesso em: 24 mar. 2008.

Artigo recebido em 16/08/10 e aprovado para publicação em14/09/10 